\title{
FRESHWATER MUSSELS (MOLLUSCA, BIVALVIA, UNIONIDAE) OF THE DANUBE RIVER BASIN OF UKRAINE
}

\author{
L. Shevchuk ${ }^{1^{*}}$, L. Vasilyeva ${ }^{1}$, M. Taradajnyk ${ }^{2}$, S. Mezhzherin ${ }^{3}$ \\ ${ }^{1}$ Department of Zoology, Biological Monitoring and Nature Conservation, \\ Zhytomyr Ivan Franko State University, Velyka Berdychivska, 40, Zhytomyr, 10004 Ukraine \\ ${ }^{2}$ Department of Medical and Biological Bases of Physical Education and Sport, \\ Zhytomyr Ivan Franko State University, Velyka Berdychivska, 40, Zhytomyr, 10004 Ukraine \\ ${ }^{3}$ Schmalhausen Institute of Zoology NAS of Ukraine, vul. B. Khmelnyskogo, 15, Kyiv, 01030 Ukraine \\ ${ }^{*}$ Corresponding author \\ E-mail: shevchuk.biol@gmail.com
}

L. Shevchuk (https://orcid.org/0000-0003-4164-514X)

L. Vasilyeva (https://orcid.org/0000-0003-0661-927X)

M. Taradajnyk (https://orcid.org/0000-0003-3993-1243)

S. Mezhzherin (https://orcid.org/0000-0003-2905-5235)

Freshwater Mussels (Mollusca, Bivalvia, Unionidae) of the Danube River Basin of Ukraine. Shevhuk, L., Vasilyeva, L., Taradajnyk, M., Mezhzherin, S. — During 2009-2011, 50 points of the Danube River Basin were surveyed. In 23 of them, seven species of Unionidae were recorded: U. pictorum, U. tumidus, U.crassus sensu lato, A. anatina, A. cygnea, P. complanata and S. woodiana, which is an invasive species. The index of occurrence of freshwater mussels in general was $100 \%$ in the Lower Danube River (5 study areas), $42 \%$ in Tisa River (31 study areas), $33.3 \%$ in Seret River (3 study areas), $36 \%$ in Prut River (11 study areas). The index of occurrence of species was rather low: $24 \%$ of A. anatina, $22 \%$ of $U$. tumidus, $22 \%$ of $U$. crassus, $16 \%$ of $U$. pictorum, $14 \%$ of P. complanata, $14 \%$ of $S$. woodiana, and $2 \%$ of A. cygnea. U. crassus was not found in the Lower Danube river, while A. cygnea was found there only outside the main watercourse. The invasive species $S$. woodiana occurred in the Lower Danube River and in the sub-basin of Tisa River with $83 \%$ and $20 \%$ frequency, respectively. The mean values of population densities ranged from 1.00 (A. cygnea) to 6.14 ind. $/ \mathrm{m}^{2}$ (S. woodiana), and the mean biomass varied from 1.14 (P. complanata) to $797.54 \mathrm{~g} / \mathrm{m}^{2}$ (S. woodiana).

Key words: Unionidae, Danube River Basin, Ukraine, species composition, abundance (population size and density), biomass.

The Danube is the longest European river that inspires significant scientific interest in studying various aspects of its functioning. As early as 2001, a team of researchers established by ICPDR (International Commission for the Protection of the Danube River) has begun the studies along the whole river (http://www.icpdr.org/ main/activities-projects/joint-danube-survey-1).

In Ukraine, the Danube River Basin covers $5.3 \%$ of the territory and occupies the southern and southeastern slopes of the Eastern Carpathians, Transcarpathia and the southwestern outskirts of the Black Sea Lowlands. It includes the rivers of Tisa, Seret, and Prut basins (the Ukrainian sections of these rivers amount to $7.3 \%$ of the total flow of the Danube), as well as several rivers that flow into the Danube or the Danube lakes below the mouth of the Prut River. The water resources of the Danube River in Ukraine belong mostly (73\%) 


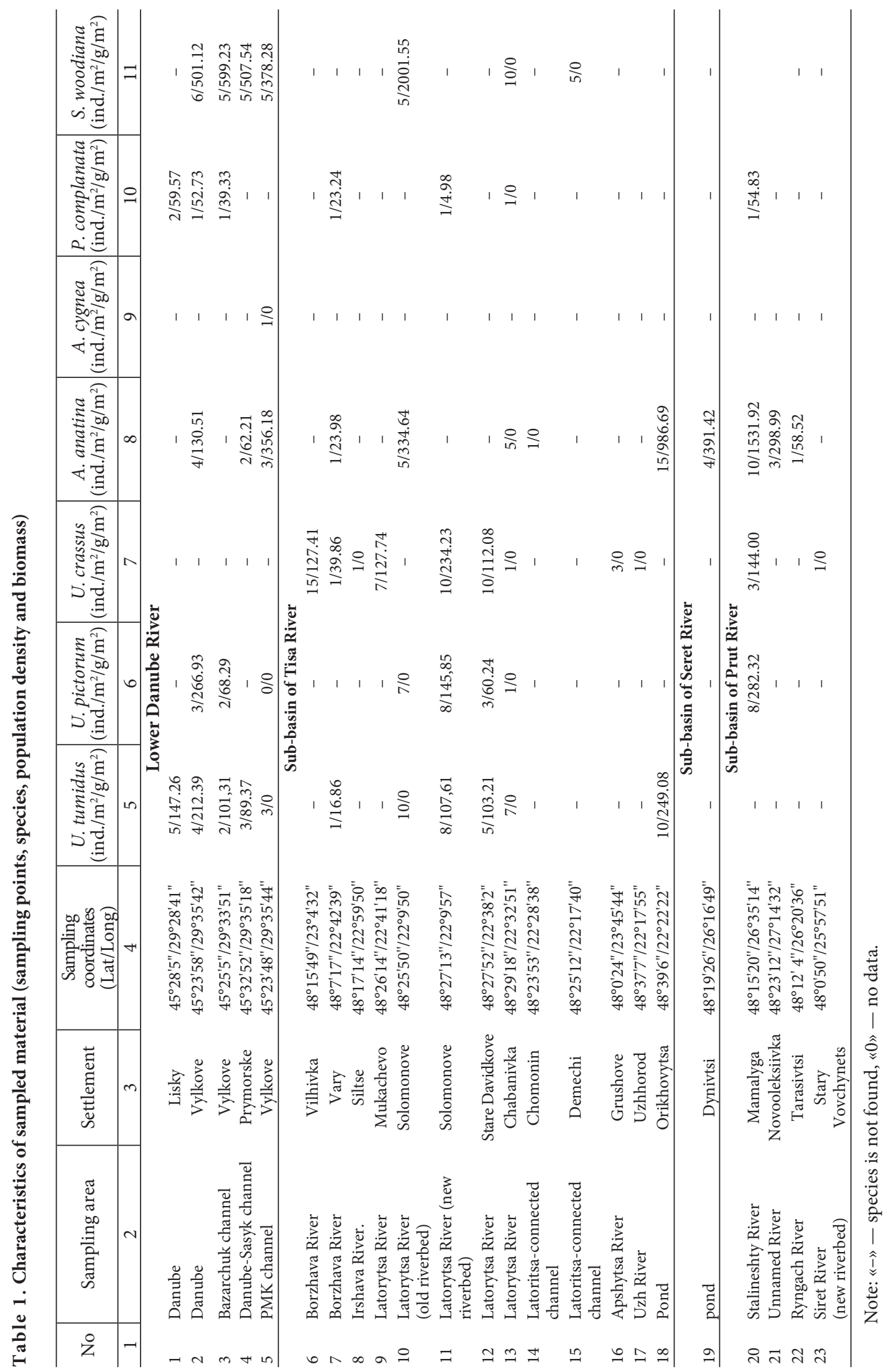


to the basin of the Tisa River, which is the Danube's largest tributary. The Ukrainian part of the Danube River is $174 \mathrm{~km}$ long, from Reni city to river's mouth. Although that is a small part of the Lower Danube, the local hydrobionts were studied extensively. However, there have been no specific studies of freshwater mussels (Mollusca, Bivalvia, Unionidae). These mussels have been studied in other Ukrainian water bodies and watercourse of the Danube River Basin in the second half of XX century (Markovsky, 1955; Zdun, 1960; Shnarevich and Ivanchik, 1963; Ivanchik, 1967, 1968; Dedyu and Mushchinsky, 1969; Polishchuk, 1974, 1977; Stadnichenko, 1984) and in Transcarpathians, only Unionidae of the Uzh were studied (Stadnichenko, 1984). The bivalve mollusks are natural filters and thus they are important components of self-sustaining purification of water bodies. A large body of scientific research indicates the importance of studying that animal group in water bodies and watercourses of the Danube River Basin in various countries of Europe (Popa, 2005;_Bódis, 2008; Sîrbu, 2006; Sîrbu et al., 2010; Bódis et al., 2011; Tomović et al., 2014). The studies of Unionidae of the Ukrainian part of the Danube River will result in better data on their systematic and chorological characteristics in different areas of the basin, will help to concentrate on the main problems of the biodiversity conservation.

There are six species of aboriginal freshwater mussels (Unionidae) of Ukraine: Unio pictorum Linnaeus, 1758, U. tumidus Philipsson, 1788, U. crassus Philipsson, 1788 (considered sensu lato in present study (Mezhzherin et al., 2013)), Anodonta anatina Linnaeus, 1758, A. cygnea Linnaeus, 1758 and P. complanata Rossmassler, 1835. The same species are found in the Danube River Basin. Moreover, the invasive species Sinanodonta woodiana Lea, 1834 was found in the Lower Danube River Basin in 1999 (Yurishinets and Kornyushin, 2001).

Hence, only the water bodies and watercourse of the Danube River Basin in Ukraine contain 7 Unionidae species (fig. 1). The studies of distribution, frequency of occurrence, specifics of population structure of those essential species of filter animals are of significant interest.

\section{Material and methods}

The samples were collected manually according to standard methods in warm seasons of 2009-2011. The material is described in tables 1 and 2 .

Table 2. Sampling areas where the mollusks were not found

\begin{tabular}{|c|c|c|c|}
\hline No & Sampling area & Settlement & $\begin{array}{l}\text { Sampling coordinates } \\
\text { (Lat/Long) }\end{array}$ \\
\hline \multicolumn{4}{|c|}{ Sub-basin of Tisa River } \\
\hline 1 & Borzhava River & Velyki Kom'yaty & $48^{\circ} 14^{\prime} 46^{\prime \prime} / 22^{\circ} 59^{\prime} 36^{\prime \prime}$ \\
\hline 2 & Latorytsa River & Pidpolozzia & $48^{\circ} 44^{\prime} 58^{\prime \prime} / 23^{\circ} 0^{\prime} 48^{\prime \prime}$ \\
\hline 3 & Latorytsa River & Svaliava & $48^{\circ} 33^{\prime} 11^{\prime \prime} / 22^{\circ} 58^{\prime} 48^{\prime \prime}$ \\
\hline 4 & $\begin{array}{l}\text { Drainage system of } \\
\text { Latorytsa River }\end{array}$ & Solomonove & $48^{\circ} 26^{\prime} 48^{\prime \prime} / 22^{\circ} 9^{\prime} 38^{\prime \prime}$ \\
\hline 5 & Latorytsa River & Tyshiv & $48^{\circ} 48^{\prime} 16^{\prime \prime} / 23^{\circ} 4^{\prime} 47^{\prime \prime}$ \\
\hline 6 & Channel, connected to Latorytsa River & Gat' & $48^{\circ} 18^{\prime} 51^{\prime \prime} / 22^{\circ} 38^{\prime} 20^{\prime \prime}$ \\
\hline 7 & Uzh River & Kam’anytsa & $48^{\circ} 41^{\prime} 22^{\prime \prime} / 22^{\circ} 25^{\prime} 25^{\prime \prime}$ \\
\hline 8 & Uzh River & Nevytske & $48^{\circ} 40^{\prime} 49^{\prime \prime} / 22^{\circ} 24^{\prime} 7^{\prime \prime}$ \\
\hline 9 & Chorni lake & Uzhhorod & $48^{\circ} 37^{\prime} 46^{\prime \prime} / 22^{\circ} 15^{\prime} 23^{\prime \prime}$ \\
\hline 10 & Tisa River & Teresva & $47^{\circ} 59^{\prime} 37^{\prime \prime} / 23^{\circ} 42^{\prime} 17^{\prime \prime}$ \\
\hline 11 & Tisa River & Khust & $48^{\circ} 10^{\prime} 9^{\prime \prime} / 23^{\circ} 16^{\prime} 33^{\prime \prime}$ \\
\hline 12 & Tereblia River & Bushtyno & $48^{\circ} 22^{\prime} 29^{\prime \prime} / 23^{\circ} 29^{\prime} 26^{\prime \prime}$ \\
\hline 13 & Teresva River & Teresva & $48^{\circ} 0^{\prime} 0^{\prime \prime} / 23^{\circ} 40^{\prime} 36^{\prime \prime}$ \\
\hline 14 & Teresva River & Teresva & $47^{\circ} 59^{\prime} 12^{\prime \prime} / 23^{\circ} 40^{\prime} 24^{\prime \prime}$ \\
\hline 15 & Roman River & Dun'kovytsa & $48^{\circ} 19^{\prime} 7^{\prime \prime} / 22^{\circ} 53^{\prime} 48^{\prime \prime}$ \\
\hline 16 & Babachka water reservoir & Sofiya & $44^{\circ} 22^{\prime} 55^{\prime \prime} / 22^{\circ} 48^{\prime} 48^{\prime \prime}$ \\
\hline 17 & Babachka channel & Zaluzhzhia & $48^{\circ} 21^{\prime} 47^{\prime \prime} / 22^{\circ} 51^{\prime} 8^{\prime \prime}$ \\
\hline 18 & pond & Sokyrnytsa & $48^{\circ} 7^{\prime} 33^{\prime \prime} / 23^{\circ} 22^{\prime} 3^{\prime \prime}$ \\
\hline \multicolumn{4}{|c|}{ Sub-basin of Seret River } \\
\hline 19 & Mykhydra River & Stara Zhadova & $48^{\circ} 12^{\prime} 34^{\prime \prime} / 25^{\circ} 30^{\prime} 7^{\prime \prime}$ \\
\hline 20 & pond & Nedoboyivtsi & $48^{\circ} 26^{\prime} 8^{\prime \prime} / 26^{\circ} 21^{\prime} 42^{\prime \prime}$ \\
\hline \multicolumn{4}{|c|}{ Sub-basin of Prut River } \\
\hline 21 & Ryngach River & Marshyntsi & $48^{\circ} 12^{\prime} 19^{\prime \prime} / 26^{\circ} 19^{\prime} 14^{\prime \prime}$ \\
\hline 22 & Prut River & Chernivtsi & $48^{\circ} 18^{\prime} 42^{\prime \prime} / 22^{\circ} 55^{\prime} 3^{\prime \prime}$ \\
\hline 23 & Kotyliv River & Koteleve & $48^{\circ} 17^{\prime} 28^{\prime \prime} / 26^{\circ} 22^{\prime} 31^{\prime \prime}$ \\
\hline 24 & Rokytna River & Novoselytsa & $48^{\circ} 13^{\prime} 5^{\prime \prime} / 26^{\circ} 16^{\prime} 18^{\prime \prime}$ \\
\hline 25 & pond & Novoselytsa & $48^{\circ} 13^{\prime} 43^{\prime \prime} / 26^{\circ} 17^{\prime} 12^{\prime \prime}$ \\
\hline 26 & Siret River (old riverbed) & Stary Vovchynets & $48^{\circ} 0^{\prime} 51^{\prime \prime} / 25^{\circ} 58^{\prime} 0^{\prime \prime}$ \\
\hline 27 & Siret River & Storozhynets & $48^{\circ} 9^{\prime} 32^{\prime \prime} / 25^{\circ} 43^{\prime} 0^{\prime \prime}$ \\
\hline
\end{tabular}



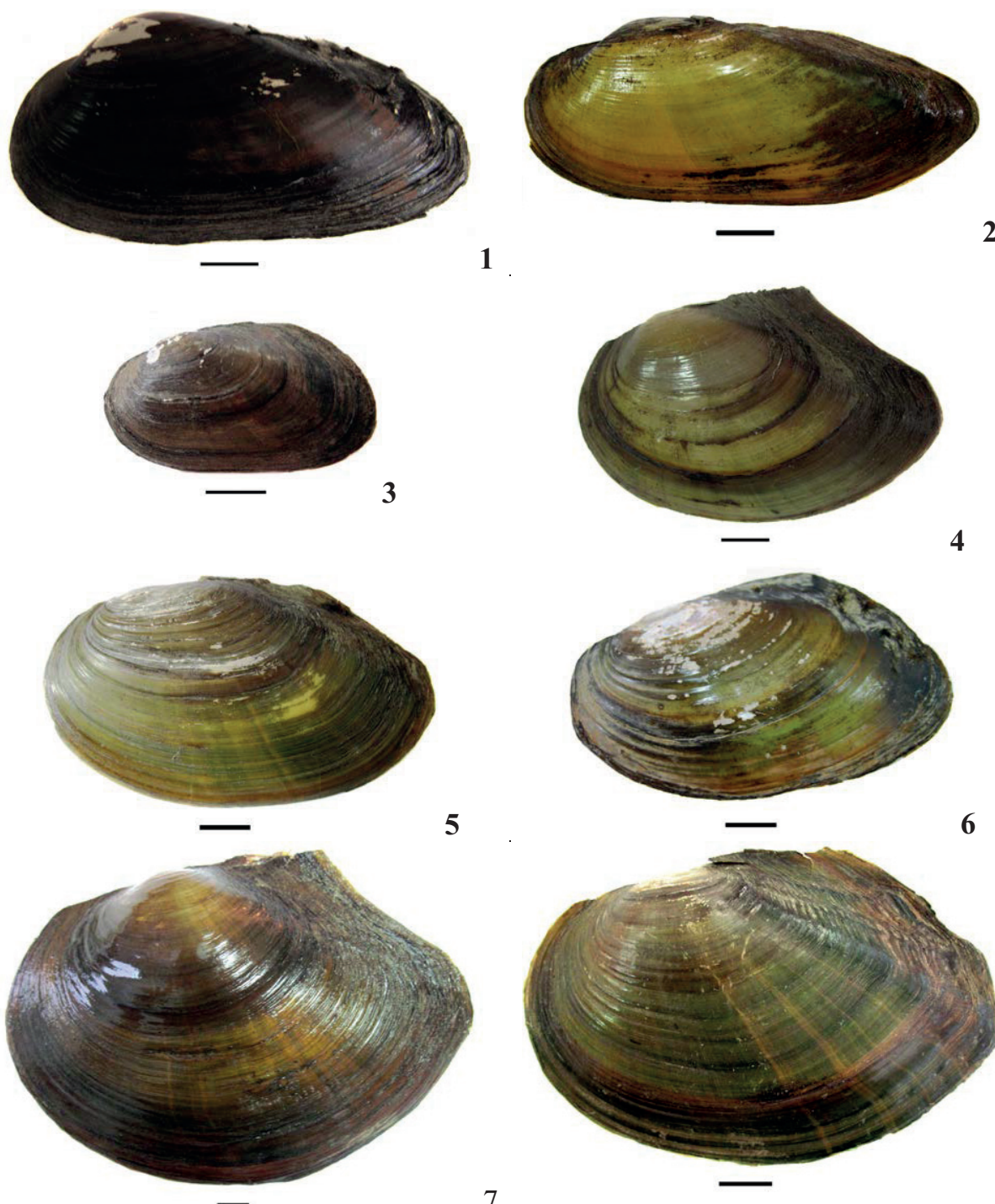

5

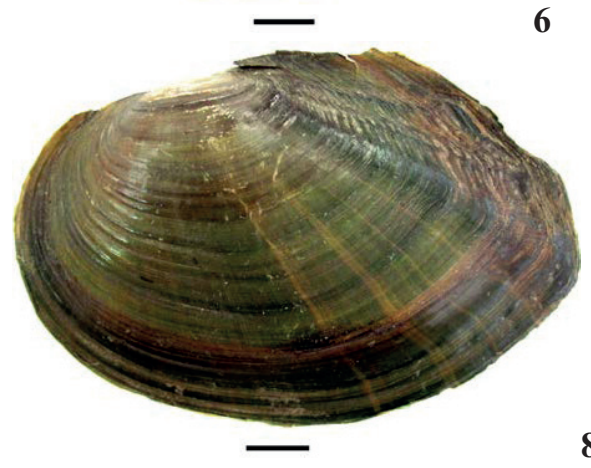

7

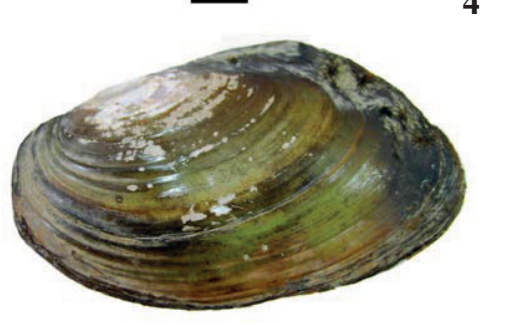

8

Fig. 1. Shells (left side): $1-U$. tumidus (the Stalineshty River, Mamalyga); $2-U$. pictorum (the Stalineshty River, Mamalyga); 3 - U. crassus (the Borzhava River, Vilkhivka); 4 - A. anatina (PMK channel, Vylkove); 5 - A. cygnea (PMK canal, Vylkove); 6 - P. complanata (the Danube River, Lisky); 7 - S. woodiana (the Danube River, Vylkove); 8 - S. woodiana (the Latorytsa River, Solomonove). Scale $10 \mathrm{~mm}$.

\section{Results and discussion}

In 2009-2011, 50 sampling points were examined in the Danube River Basin. Unionidae mussels were found only in 23 of them $(46 \%$ ) (tables 1,2$)$. The frequency of occurrence of Unionidae mussels (our data) was compared to data of other researchers on these mussels of other water basins of Ukraine (table 3). The state of Unionidae populations in the studied basin is not encouraging.

The obtained results showed (table 4 ) that 16 sampling areas which contained mussels were in rivers, 5 in channels and 2 in ponds. Unionidae populations were absent in rivers (54\%), in all water reservoirs and lakes (100\%), in the majority of ponds (60\%) and in a number of channels (37.5\%). 
Notably, the frequency of occurrence of freshwater mussels varied in different parts of the Danube River Basin. This was reflected in the ratio of study areas where the mollusks were found to all study areas. Thus, this parameter was $100 \%$ for the Lower Danube (5 study areas in total), $42 \%$ for the sub-basin of the Tisa River (31 study areas in total), $33.3 \%$ for the sub-basin of the Seret ( 3 study areas in total), $36 \%$ for the sub-basin of the Prut (11

study areas in total). Previously, the populations of freshwater mussels were observed at the whole riverbed (Bartosh, 1938; Sarkany-Kiss, 1997). This is infrequent now.

Species richness (table 1) is an important characteristic of a community. Thus, 6 species of mollusks (U. pictorum, U. tumidus, U. crassus, A. anatina, P. complanata, S. woodiana) were found in 1 biotope (the Latorytsa River, Chabanivka village, Zakarpattia Region of Ukraine), 5 species in 2 biotopes (the Danube River and PMK channel, Vylkove, Odesa Region of Ukraine), and 4 species in 5 biotopes (the Borzhava River, Vary village, Zakarpattia Region; Latorytsa River (old and new riverbed), Solomonove village, Zakarpattia Region; Stalineshty River, Mamalyga village, Chernivtsi Region; Bazarchuk channel, Vylkove, Odesa Region). 2 species, (U. tumidus and A. anatina) were found in a pond of Orichovytsa village, Zakarpattia Region, and in the Danube River, Lisky village, Odesa Region (U. tumi$d u$ and $P$. complanata). 11 communities were monospecific, 8 of them in rivers: 6 of river communities were composed of $U$. crassus, 4 communities were of $A$. anatina, and 1 was of S. woodiana. The species composition of Unionidae in the rivers of the Danube River Basin was the most various compared to those of other river basins (Yanovych, 2013).

Table 4. Frequency of occurrence of Unionidae freshwater mussels in Danube River Basin and number of species in study area

\begin{tabular}{l|c|c|c|c|c|c|c|c|c}
\hline \multirow{2}{*}{$\begin{array}{c}\text { Type of water } \\
\text { body }\end{array}$} & \multirow{2}{*}{$\begin{array}{c}\text { Number of } \\
\text { study areas }\end{array}$} & \multirow{2}{*}{$\begin{array}{c}\text { Study areas with } \\
\text { Unionidae }\end{array}$} & \multicolumn{6}{c}{ Study areas with the noted number of mollusk } \\
\cline { 4 - 10 } & & & $\mathbf{6}$ & $\mathbf{5}$ & $\mathbf{4}$ & $\mathbf{3}$ & $\mathbf{2}$ & $\mathbf{1}$ & $\mathbf{0}$ \\
\hline River & 35 & 16 & 1 & 1 & 4 & 1 & 1 & 8 & 19 \\
Water reservoir & 1 & 0 & - & - & - & - & - & - & 1 \\
Lake & 1 & 0 & - & - & - & - & - & - & 1 \\
Pond & 5 & 2 & - & - & - & - & 1 & 1 & 3 \\
Channel & 8 & 5 & - & 1 & 1 & 1 & - & 2 & 3 \\
\hline
\end{tabular}

Table 5. Frequency of occurrence (\%) of freshwater mussels in various parts of the Danube River Basin

\begin{tabular}{l|c|c|c|c}
\hline $\begin{array}{c}\text { Species } \\
\text { of mollusk }\end{array}$ & $\begin{array}{c}\text { Lower } \\
\text { Danube River }\end{array}$ & $\begin{array}{c}\text { Sub-basin } \\
\text { of Tisa River }\end{array}$ & $\begin{array}{c}\text { Sub-basin } \\
\text { of Seret River }\end{array}$ & $\begin{array}{c}\text { Sub-basin } \\
\text { of Prut River }\end{array}$ \\
\hline U. pictorum & 40 & 33 & - & 25 \\
U. tumidus & 83 & 40 & - & - \\
U. crassus & - & 73 & - & 50 \\
A. anatina & 67 & 33 & 100 & 75 \\
A. cygnea & 17 & - & - & - \\
P. complanata & 50 & 20 & - & 25 \\
S. woodiana & 83 & 20 & - & - \\
\hline
\end{tabular}


The frequency of occurrence of some freshwater mussel species and their abundance are of particular interest in the Danube River Basin (table 5).

Overall the frequency of occurrence of Unionidae was low in the Danube River Basin: $16 \%$ for U. pictorum, $22 \%$ for U. tumidus, $22 \%$ for U. crassus, $24 \%$ for A. anatina, $2 \%$ for A. cygnea, $14 \%$ for P. complanata and for S. woodiana. Interestingly, the index was rather high for $U$. crassus and very low for A. cygnea.

Thus, according to literature, $U$. pictorum has already been recorded in the Danube watercourse (Markovsky, 1955; Zdun, 1960; Shnarevich and Ivanchik, 1963; Ivanchik, 1967, 1968; Dedyu and Mushchinsky, 1969; Polishchuk, 1974, 1977; Stadnichenko, 1984). It was found in various areas of the watercourse. According to our data, the frequency of occurrence of that species was $16 \%$. However that parameter varied in different areas of the Danube River Basin. Thus, the species was found in 2 of 5 study areas (frequency of occurrence $40 \%$ ) in the Lower Danube River, in 5 of 15 study areas (33\%) in the sub-basin of the Tisa River, in 1 of 4 study areas (25\%) in the sub-basin of the Prut River. It was absent in the single study area in the sub-basin of the Seret River.

U. tumidus has also been considered a common species of Unionidae in Ukraine, because it occurred in all natural geographical zones and was numerous (Stadnichenko, 1984). It has been found in the Danube River Basin, too (Gaidash, 1971; Markovsky, 1955; Ivanchik, 1964, 1967, 1968; Polishchuk, 1974, 1977; Kornyushin and Lyashenko, 2004). In present study, it was found in the Lower Danube and sub-basin of the Tisa River, with 83 and $40 \%$ frequency of occurrence, respectively.

U. crassus has been previously recorded in rivers Tisa, Prut, Uzh, and in the estuaries of the Danube Delta (Zhadin, 1938; Markovsky, 1955; Cheremisina and Ivanchik, 1955; Ivanchik, 1967, 1968; Polishchuk, 1977; Stadnichenko, 1984; Kornyushin and Lyashenko, 2004). However, the findings in the Danube Delta are rather controversial, because they have not been confirmed by the numerous surveys conducted by other authors in this region. We did not find this species in the Lower Danube. In the sub-basin of the Tisa River its frequency of occurrence was $73 \%$, and in the sub-basin of the Prut River it was $50 \%$.

A. anatina is also a common mollusk species in Ukraine. It has been observed in the Lower Danube River Basin and in Transcarpathia rivers (Markovsky, 1955; Zdun, 1960; Ivanchik, 1968; Polishchuk, 1977). We found it in water bodies and watercourse of the Lower Danube (frequency of occurrence $67 \%$ ), and in sub-basins of the Tisa (33\%), Seret (100\%), and Prut (75\%).

A. cygnea prefers the lakes and floodplain water bodies with clean water. It has not been recorded previously in the Danube River Basin in Ukraine. We found that species in a single study area in the Lower Danube (17\% frequency of occurrence). The unevenness of distribution of this species has been noted by other researchers. The species is frequently absent in samples, or present as hollow shells (Popa, 2005; Sîrbu et al., 2010; Tomović et al., 2014; Bódis et al., 2015).

P. complanata was rather common in Ukraine until 1970s-1980s, though with low abundance. It has been observed in the basin of the Lower Danube River and Transcarpathia rivers (Markovsky, 1955; Zdun, 1960; Ivanchik, 1967; Polishchuk, 1974, 1977). We found it in the Lower Danube (50\% frequency of occurrence) and the sub-basins of the Tisa $(20 \%)$ and Prut (25\%).

In 2001, invasion of $S$. woodiana has been reported in the aquatic coenoses of Ukraine, in the Lower Danube Basin (Yurishinets and Kornyushin, 2001). We have found it in the Lower Danube River and in watercourses of Transcarpathia, particularly in the old riverbed of the Latorytsa River in 2010 (Pampura and Yanovich, 2012). In 2011, that species was found not only in the main riverbed of the Latorytsa River (Solomonove and Chabanivka villages) but also in its system of channels (Demechi village). S. woodiana was found in 7 study areas, 3 of them were rivers 4 were channels. It was the only species in the channel, connected to the Latorytsa River (Demechi village, Zakarpattia Region). In other areas, 
it co-existed with $U$. pictorum (in 5 biotopes), $U$. tumidus (6), U. crassus (1), P. complanata (3), A. anatina (5), and A. cygnea (1) mollusks. The invasive species had the total frequency of occurrence of $83 \%$ in the Lower Danube River, and $20 \%$ in the sub-basin of the Tisa River.

Various species of freshwater mussels had different population density and biomass in the water bodies and watercourses of the Danube River Basin (table 6).

The analysis of density of $U$. pictorum populations showed that the mean density was $4.5 \mathrm{ind} . / \mathrm{m}^{2}$, ranging from 1 to $8 \mathrm{ind} . / \mathrm{m}^{2}$. The highest population density of that species, 7 and 8 ind. $/ \mathrm{m}^{2}$ was recorded in the sub-basin of the Tisa River (the Latorytsa River, the new and old riverbeds, respectively), in Solomonove village, Zakarpattia Region. In the same region, the lowest population density was observed for that species too. In the Lower Danube River, that parameter was 2-3 ind. $/ \mathrm{m}^{2}$ (the Bazarchuk channel in Vylkove, Odesa Region, and the Danube River also in Vylkove, respectively). The biomass of mollusks per $1 \mathrm{~m}^{2}$ of biotope was not high either, the mean biomass was $186.05 \pm 44.16 \mathrm{~g} / \mathrm{m}^{2}$ in the Lower Danube River Basin.

The population density of $U$. tumidus did not significantly differ from the abovementioned, although the frequency of occurrence was higher. The mean density was only $5.27 \mathrm{ind} . / \mathrm{m}^{2}$, in the range of $1-10 \mathrm{ind} . / \mathrm{m}^{2}$. The maximum population density $\left(7-10 \mathrm{ind} . / \mathrm{m}^{2}\right)$ was recorded in the sub-basin of the Tisa River, namely in the Latorytsa River. In the Lower Danube, that parameter ranged from 3 to $5 \mathrm{ind} . / \mathrm{m}^{2}$. Notably, in the second half of XX century, the density of $U$. tumidus population has been 80 ind. $/ \mathrm{m}^{2}$ in the Danube River Basin (Prut River) (Ivanchik, 1968). The species was able to sustain enormous populations of $850 \mathrm{ind} . / \mathrm{m}^{2}$ (the Siret River) (Ivanchik, 1968), or even 2680 ind. $/ \mathrm{m}^{2}$ (the Vovcha River) (Gaidash, 1971). Currently the mean biomass of the species was $132.90 \pm 23.34 \mathrm{~g} / \mathrm{m}^{2}$ in the river basin.

The population density of $U$. crassus was $25-416$ ind./ $\mathrm{m}^{2}$ in the Prut River Basin in the middle of XX century (Ivanchik, 1959). Now, it became one of the lowest among the Unionidae species in Ukraine (Shevchuk (Yanovych) et al., 2019). According to our data, the highest density was recorded in the Danube River Basin $\left(4.82 \pm 1.48\right.$ ind. $\left./ \mathrm{m}^{2}\right)$. The maximum population density $\left(15 \mathrm{ind} . / \mathrm{m}^{2}\right)$ was recorded only in 1 study area in the subbasin of the Tisa River (the Borzhava River, Vilkhivka village, Zakarpattia Region). In two areas at the Latovytsa River (Stare Davydkove and Solomonove villages of Zakarpattia

Table 6. Mean (M), standard deviation $(\mathrm{m})$ and range (min-max) of population density and biomass of Unionidae in the Danube River Basin

\begin{tabular}{|c|c|c|c|}
\hline \multirow{2}{*}{ Species of mollusk } & \multirow{2}{*}{$\begin{array}{l}\text { Number of } \\
\text { samples }\end{array}$} & $\begin{array}{c}\text { Population density of mollusks, } \\
\text { ind./m² }\end{array}$ & $\begin{array}{c}\text { Biomass of mollusks, } \\
\mathrm{g} / \mathrm{m}^{2}\end{array}$ \\
\hline & & $\begin{array}{c}\mathrm{M} \pm \mathrm{m} \\
(\min -\max )\end{array}$ & $\begin{array}{c}\mathrm{M} \pm \mathrm{m} \\
(\min -\max )\end{array}$ \\
\hline U. pictorum & 8 & $\begin{array}{l}4.50 \pm 0.98 \\
(1-8)\end{array}$ & $\begin{array}{l}186.05 \pm 44.16 \\
(60.24-292.70)\end{array}$ \\
\hline U. tumidus & 11 & $\begin{array}{l}5.27 \pm 0.94 \\
\quad(1-10)\end{array}$ & $\begin{array}{c}132.90 \pm 23.34 \\
(16.86-249.34)\end{array}$ \\
\hline U. crassus & 11 & $\begin{array}{l}4.82 \pm 1.48 \\
(1-15)\end{array}$ & $\begin{array}{c}130.89 \pm 25.50 \\
(39.86-234.23)\end{array}$ \\
\hline A. anatina & 12 & $\begin{array}{l}4.50 \pm 1.20 \\
(1-15)\end{array}$ & $\begin{array}{c}417.51 \pm 52.15 \\
(23.98-1531.92)\end{array}$ \\
\hline A. cygnea & 1 & $\begin{array}{l}1.00 \\
(1)\end{array}$ & - \\
\hline P. complanata & 7 & $\begin{array}{l}1.14 \pm 0.14 \\
\quad(1-2)\end{array}$ & $\begin{array}{c}39.12 \pm 8.69 \\
(4.98-59.57)\end{array}$ \\
\hline S. woodiana & 7 & $\begin{array}{l}6.14 \pm 0.705 \\
\quad(5-10)\end{array}$ & $\begin{array}{c}797.54 \pm 303.04 \\
(378.28-2001.550)\end{array}$ \\
\hline
\end{tabular}


Region), 9-11 individuals of the species were recorded per $1 \mathrm{~m}^{2}$, which is one of the highest indices for Ukraine. The mean biomass of $U$. crassus individuals was $130.89 \pm 25.50 \mathrm{~g} / \mathrm{m}^{2}$ in the Danube River Basin.

Although A.anatina is one of the most common species of Unionidae in the Danube River Basin, its mean population density is low, $4.50 \pm 1.20$ ind. $/ \mathrm{m}^{2}$. The maximum density was only $15 \mathrm{ind} . / \mathrm{m}^{2}$, recorded in a single study area in the sub-basin of the Tisa River (a pond, Orikhovytsa village, Zakarpattia Region). The biomass of individuals was $417.51 \pm 52.15 \mathrm{~g} / \mathrm{m}^{2}$ in the river basin, which is the highest for Ukraine (Yanovych, 2013)). The highest biomass was recorded in a study area in the sub-basin of the Prut River, namely in the Stalineshty River, Mamalyga village of Chernivtsi Region $\left(1531.92 \mathrm{~g} / \mathrm{m}^{2}\right)$. The biomass of A. anatina mollusks has been $1400 \mathrm{~g} / \mathrm{m}^{2}$ in the Prut River basin in the middle of XX century (Ivanchik, 1964).

A. cygnea was one of the rarest species under study, with the lowest frequency of occurrence and population density among the Unionidae of the Danube River. We found only 1 individual of this species in the Lower Danube River (PMK channel, Vylkove town, Odesa Region). That mollusk's population density has been as high as $48 \mathrm{ind} . / \mathrm{m}^{2}$ in the watercourses of the Ukrainian Carpathians in the second half of XX century (Ivanchik, 1967).

$P$. complanata was a species with the lowest population density among the freshwater mussels in Ukraine and in the Danube River Basin particularly. We observed its maximum population density ( 2 ind. $/ \mathrm{m}^{2}$ ) only in the Danube River (Lisky village, Odesa Region). In other study areas the parameter was 1 ind. $/ \mathrm{m}^{2}$. The mean biomass in the Danube River Basin was $39.12 \pm 8.69 \mathrm{~g} / \mathrm{m}^{2}$. Overall, the low abundance in populations of all European Unionidae species in other waterbodies of the Danube River has been noted by other researchers (Bódis et al., 2015).

In contrast, we found the maximum population density of $S$. woodiana, 10 ind. $/ \mathrm{m}^{2}$, in a study area in the sub-basin of the Tisa River (the Latorytsa River, Chabanivka village, Zakarpattia Region). In 2 other study areas (one of them also in the sub-basin of the Tisa River, one in the Lower Danube River), 6 and 7 individuals per $1 \mathrm{~m}^{2}$ were found, respectively. The mean biomass of invasive species $S$. woodiana was the highest of all recorded values, $\left.797.54 \pm 303.04 \mathrm{~g} / \mathrm{m}^{2}\right)$. The biomass in a single study area was also the highest recorded $\left(2001.55 \mathrm{~g} / \mathrm{m}^{2}\right)$ in the Latorytsa River (Solomonove village, Zakarpattia Region), with the low density of $5 \mathrm{ind} . / \mathrm{m}^{2}$. However, the biomass of $25 \mathrm{~kg} / \mathrm{m}^{2}$ was observed in the Konin lakes, Poland (Kraszewski, Zdanowski, 2001).

\section{Conclusions}

According to our results, Unionidae mollusks were found in 23 of 50 study areas (46\%) during the survey of the Danube River Basin in 2009-2011. The frequency of occurrence was $100 \%$ in the Lower Danube River (5 study areas), $42 \%$ in the sub-basin of the Tisa River (31 study areas), $33.3 \%$ in the sub-basin of Seret (3 study areas), $36 \%$ in the sub-basin of the Prut (11 study areas).

The Danube River Basin is the only river basin of Ukraine populated by 7 species of freshwater mussels: U. pictorum, U. tumidus, U. crassus (here, sensu lato), A. anatina, A. cygnea, $P$. complanata and $S$. woodiana. The latter species is invasive.

The frequency of occurrence of freshwater mussels is low in the Danube River Basin: U. pictorum, $16 \%$; U. tumidus, $22 \%$; U. crassus, $22 \%$; A. anatina, $24 \%$; A. cygnea, $2 \%$, P. complanata, $14 \%$, and S. woodiana, $14 \%$. U. crassus is not found in the Lower Danube, and A. cygnea is found only there. S. woodiana is found both in the Lower Danube and in the sub-basin of the Tisa River (the frequency of occurrence is 83 and $20 \%$, respectively).

The mean values of population density of the studied species range from 1.00 (A. cygnea) to 6.14 ind. $/ \mathrm{m}^{2}$ (S. woodiana). The mean values of biomass ranged from 1.14 (P. complanata) to $797.54 \mathrm{~g} / \mathrm{m}^{2}$ (S. woodiana). Thus, maximum values of those parameters are characteristic for the invasive species, the Chinese pond mussel. 


\section{References}

Bartosh, A. A. 1938. Biology and reserves of pearl barley of the Kubnya River. Zap. o-va estestvoispy 'tatelej pri Kazan. un-te, 3/4, 69-94 [In Russian].

Bódis, E. 2008. Contribution to the macroinvertebrate fauna of the Hungarian Danube IV. Mussels (Bivalvia: Corbiculidae, Dreissenidae, Sphaeriidae, Unionidae). Folia Historico-Naturalia Musei Matraensis, 32, 57-68.

Bódis, E., Nosek, J., Oertel, N., Tóth, B., Hornung, E., Sousa, R. 2011. Spatial distribution of bivalves in relation to environmental conditions (Middle Danube catchment, Hungary). Community Ecology, 12, 210-219.

Bódis E., Tóth B., Sousa R. 2015. Freshwater mollusc assemblages and habitat associations in the Danube River drainage, Hungary. Aquatic Conservation: Marine and Freshwater Ecosystems, 26 (2), 319-322.

Dedyu, I. I., Mushchinsky, V. G. 1969. Composition and quantitative characteristics of the bottom fauna of the Prut River. In: Limnologicheskie issledovaniya Dunaya. Naukova Dumka, Kiev, 299-303 [In Russian].

Cheremisina, V. T., Ivanchik, G. S. 1955. Density and growth rate of common pearl barley in the rivers of the Chernivtsi region. Pratsi ekspedytsii Chernivetsk. un-tu, 1 (4), 142-149 [In Russian].

Gaidash, Yu. K. 1971. Distribution of molluscs in reservoirs salinized with mine waters. In: Mollyuski. Puti, metody' i itogi ikh izucheniya. Nauka, Leningrad, 98-99 [In Russian].

International studies of the Danube River. 2019. Available from: http://www.icpdr.org/main/activities-projects/ joint-danube-survey-1

Ivanchik, G. S. 1959. On the question of the ecological distribution of Unio crassus Retz. in the basins of the Seret and Prut rivers. Fauna i zhivotny 'j mir Sovetskikh Karpat: nauchny'e zapiski Uzhgorodskogo gosudarstvennogo universiteta, 40, 345-349 [In Russian].

Ivanchik, G. S. 1964. Ecological and geographical characteristics of freshwater mollusks of the Soviet Carpathians and the Prykarpattia. In: Tez. dokl. XX nauch. sessii Chernovicz. un-ta. Sekcziya biol. Nauk, $102-105$ [In Russian].

Ivanchik, G. S. 1967. Freshwater mollusks of the Ukrainian Carpathians. PhD Thesis, biol. sciences. Chernovczy, 1-22 [In Russian].

Ivanchik, G. S. 1968. Distribution and growth rate of Unionids in the upper reaches of the Dniester, Prut and Seret rivers. Mollyuski i ikh rol'v ekosistemakh: Avtoref. Dokladov, 3, 56-57 [In Russian].

Kornyushin, A. V., Lyashenko, A. V. 2004. Malakofauna of the lower reaches of the Danube within Ukraine. Gidrobiologicheskij zhurnal, 40 (1), 3-19 [In Russian.]

Kraszewski, A., Zdanowski, B. 2001. The distribution and abundance of the Chinese mussel Anodonta woodiana (Lea, 1834) in the heated Konin lakes. Archives of Polish Fisheries, 9 (2), 253-265.

Markovsky, Yu. M. 1955. Fauna of invertebrates in the lower reaches of the rivers of Ukraine, conditions of its existence and ways of using. Part 3. Reservoirs of the Kiliya delta of the Danube. Izd-vo AN UkrSSR, Kiev, 1-280 [In Russian].

Mezhzherin, S. V., Yanovych, L. M., Zhalay, Y. I., Pampura, M. M., Vasilieva, L. A. 2013. Reproductive isolation of two Unio crassus Philipsson, 1788 (Bivalvia, Unionidae) vicarious forms with low genetic differentiation level. Dopovidi Natsionalnoi akademii nauk Ukrainy, 2, 138-143 [In Russian].

Pampura, M. M, Yanovich, L. M. 2012. New find of Sinanodonta woodiana (Bivalvia, Unionidae) in the Danube basin of Ukraine (morphobiological characteristics). Naukovyi visnyk Uzhhorodskoho universytetu. Seriia: Biolohiia, 32, 145-149 [In Russian].

Polishchuk, V. V. 1974. Hydrofauna of the lower Danube within Ukraine. Naukova Dumka, Kiev, 11-331 [In Ukrainian].

Polishchuk, V. V. 1977. Composition, geographical features and genesis of hydrofauna of water bodies of Ukraine. Doctoral thesis in biology, Kiev, 125-126 [In Russian].

Popa, O. P., 2005. Contributions to the knowledge of the mollusks from the Romanian Sector of the Danube between Calafat and Oltenipa. Travaux du Muséum National d'Histoire Naturelle. Grigore Antipa, 48, 7-19.

Sarkany-Kiss, A. 1997. The present-day situation of the Unionidae (Mollusca: Bivalvia) in the transylvanian tributaries of the Tisa river (Romania). Travaux du Muséum National d'Histoire Naturelle. Grigore Antipa, 37, 213-224.

Sîrbu, I. 2006. Aspects concerning the distribution and ecology of the freshwater molluscs from the Romanian Inner Carpathian Basin. Heldia. München, 6 (3-4), 115-134.

Sîrbu, I., Sîrbu, M., Benedek A. M. 2010. The freshwater mollusca fauna from Banat (Romania). Travaux du Muséum National d'Histoire Naturelle. Grigore Antipa, 53, 21-43.

Shevchuk (Yanovych), L. M., Vasilieva, L. A., Taradainyk (Pampura), M. M., Mezhzheryn, S. V. 2019. Justification for the necessity of registrationin the Red Data Book of Ukraine the Unio crassus Philipsson, 1788 (Mollusca, Bivalvia, Unionidae). Biolohiia ta ekolohiia, 5 (2), 32-40 [In Ukrainian].

Shnarevich, I. D., Ivanchik, G. S. 1963. Distribution and industrial reserves of bivalve mollusks in the reservoirs of the Carpathians and the possibility of their use in trout farming. In: Materialy do vyvchennia pryrodnykh resursiv Podillia. Vyd-vo Kremenetsk. ped. in-tu, Ternopil-Kremenets, 187-188 [In Ukrainian].

Stadnichenko, A. P. 1984. Fauna of Ukraine. Pearl. Ball (Unionidae, Cycladidae). Naukova Dumka, Kiev, 1-167 [In Russian]. 
Tomović, J., Paunović, M., Atanacković, A., Marković, V., Gačić, Z., Csányi, B., Simić, V. 2014. Biotic Typology of the Danube River Based on Distribution of Mollusc Fauna as Revealed by the Second Joint Danube Survey. Acta zoologica bulgarica, 66 (4), 527-537.

Yanovych, L. M. 2013. Pearl Unionidae Rafinesque, 1820 (Bivalvia) in modern ecological conditions of Ukraine (state of populations, features of sexual structure and reproduction, biocoenotic connections and fauna). Doctoral thesis in biology, Zhytomyr, 1-56 [In Ukrainian].

Yurishinets, V. I., Kornyushin A. V. 2001. A new species of bivalve mollusks Sinanodonta woodiana (Bivalvia, Unionidae) for the fauna of Ukraine, its diagnostics and possible ways of introduction. Vestnik Zoologii, 35 (1), 79-84 [In Russian].

Zdun, V. I. 1960. To the fauna of mollusks in Transcarpathia. Naukovi zapysky naukovo-pryrodoznavchoho muzeiu AN URSR, VIII, 83-94.

Zhadin, V. I. 1938. Fauna of the USSR. T. 4. Mollusks of the family Unionidae. Izd-vo AN UkrSSR, MoscowLeningrad, 1-167 [In Russian].

Received 14 September 2020

Accepted 5 January 2021 